\title{
Deposition of Malene supracrustal rocks on an Amîtsoq basement in outer Ameralik, southern West Greenland
}

\author{
Allen P. Nutman and David Bridgwater
}

\begin{abstract}
Contact relations between Amîtsoq gneisses and Malene supracrustal rocks are described from Simuitâ and Qilángârssuit. It is concluded that primary depositional contacts are still preserved at some localities and that local apparent gradational features may represent a regolith. The sequence on Simuitâ is: Amîtsoq gneiss, banded white quartzite, mica schist with 'chert' and amphibolite. Primary layering in the lower unit is continuous and not truncated at the contact with the gneisses. The suggested primary contact and composition of the quartzitic unit are consistent with derivation by rapid weathering of older sial to form a quartz-rich arkose. The overlying mica schists are highly ferromagnesian and have high $\mathrm{Cr}$ and $\mathrm{Ni}$ contents suggesting a possible basic source. The amphibolite is interpreted as being derived from original layered basic igneous parent probably tuffs interlayered with differentiated sills.

The succession on Qilángârssuit consists of basal mica schists and 'cherts', amphibolites, and an upper Al-rich metasediment unit. The lower units are interpreted as deposited on an Amitsoq gneiss basement. The upper unit is progressively cut off to the north by a thrust contact with an overlying Amîtsoq gneiss unit. The differences between the basal Malene sequences over 12-15 km suggest they represent local, near-shore depositional environments rather than more extensive ocean basins.
\end{abstract}

\section{Introduction}

In his original description of the lithostratigraphic framework of the Godthåbsfjord gneiss complex McGregor (1973) pointed out that the contacts between Amitsoq gneisses and Malene supracrustal rocks that had been examined were either tectonic or undecipherable. Thus there was no proof of which was the older or of the relation between them prior to deformation. The (dated) Amîtsoq gneisses must have formed a 'continental' mass at 3600 Ma. The Malene supracrustal rocks could have been 'oceanic' crust of any age earlier than $3000 \mathrm{Ma}$ that was intercalated with the Amitsoq gneisses during the tectonic event which controlled the injection of Nûk gneiss sheets, or they counld have been a pre-3000 Ma cover sequence deposited on an Amîtsoq gneiss basement. The interpretation of Amîtsoq Malene relations is made more by difficult the effects of at least three phases of intense, heterogeneous deformation since the formation of the Malene supracrustal rocks (Bridgwater et al., 1974; Chadwick \& Nutman, 1979), see Table 1. Furthermore, as the finite strain of Malene supracrustal rocks varies considerably throughout the area, correlation and comparison between different Malene sequences is difficult. 
Table 1. Relevant geological events in the outer Ameralik - northwestern Buksefjorden région

6 (youngest) $D_{4}$ deformation; irregular upright folds and basin and dome structures. Amphibolite facies metamorphism.

$5 \quad D_{3}$ deformation; formation of large nappe structures and the intrusion of the Nak gneisses at ca. $3000 \mathrm{Ma}$.

$4 D_{2}$ deformation; interleaving of Malene supracrustal rocks and Amîtsoq gneisses by thrusting.

3 Depositon of Malene supracrustal rocks, followed or accompanied by the intrusion of Malene basic dykes. Basement to the Malene sequence is considered to have been Amitsoq gneiss.

2 Intrusion of Ameralik dykes.

1 (oldest) Stabilisation of thick Amitsoq gneiss crust and amphibolite-granulite facies metamorphism at 3500-3600 Ma.

There have been several attempts to solve the Amîtsoq - Malene problem isotopically. Rb-Sr whole-rock dating (R. J. Pankhurst, personal communication, 1975) yielded a scatter between 2500 and 2800 reference isochrons with considerable range in Sr initial ratios from different suites. The Malene supracrustal rocks thus gave an age younger than the Nûk gneisses that intrude them and no consistent $\mathrm{Sr}$ isotope evidence of a long crustal history. Zircons separated from large samples of Malene metasediment collected in 1973 (D. B. and V. R. McGregor) in the hope of obtaining the age of the rocks from which they were derived gave metamorphic ages in the range 2500-3000 Ma (Baadsgaard, 1976), although some of the zircons show forms similar to those separated from Amitsoq gneisses. There is some correlation between the concordia intercept ages and the ages obtained from adjacent gneiss units. Thus zircons separated from the Ivisârtoq supracrustal belt have yielded younger ages than other Malene supracrustal units, which are interpreted as due to the presence of Qôrqut granite sheets in the area. Studies of zoned zircons using an ion probe are in progress at Cambridge University.

Beech (1979) made a comprehensive study of the morphology of zircons from Malene supracrustals of the northwestern Buksefjorden region (fig. 1) and reported that some populations show forms consistent with derivation from continental crust. Chadwick \& Nutman (1979) made detailed studies of field relations in the Qilángârssuit area and suggested that some Malene amphibolite - Amitsoq gneiss contacts may be deformed unconformities. They described local preservation of thin units of 'basal sediment'. These are either brown micaceous rock with green (chromiferous) mica, biotite, quartz, microcline and plagioclase, or a non-clastic quartzite containing green (chromiferous) mica. Although this model was provisionally accepted by other geologists who visited these contacts (Bridgwater et al., 1979), doubts were expressed about the validity of some of the evidence cited, for example, the truncation of pegmatites in the Amitsoq gneisses at the contacts could apply equally well to a purely tectonic model. Work further north on the arkosic Malene supracrustals from Rypeø (fig. 1) by Dymek et al. (1983) supports the contention that Malene sediments were derived from sialic crustal rocks. 
Fig. 1. Outcrops of Malene supracrustal rocks in the northwestern Buksefjorden - outer Ameralik region. This figure was compiled from mapping by V. R. McGregor, B. Chadwick and A. P. Nutman.

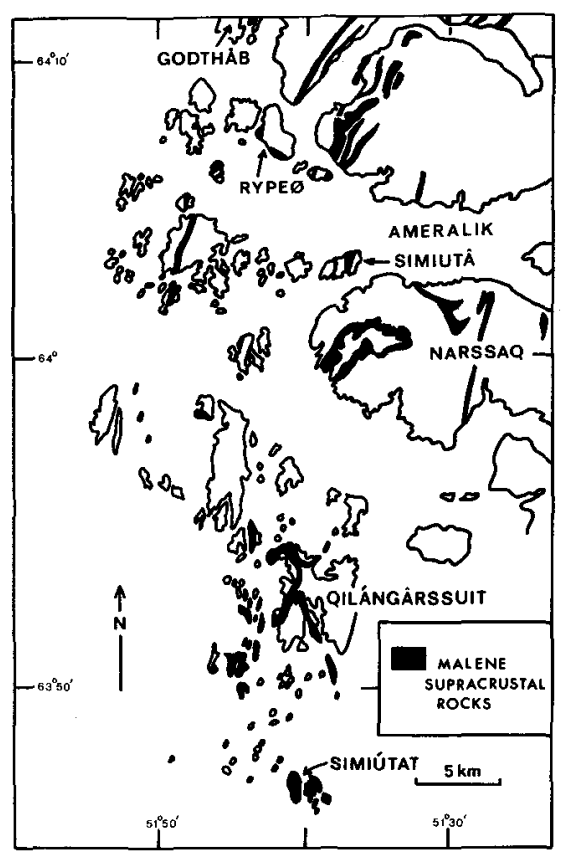

\section{Malene sequences and their relations with adjacent Amîtsoq gneisses}

Malene Amîtsoq relations were examined in 1980 on Simuitâ (fig. 1) where there is a well-preserved Malene supracrustal sequence comprised of quartzites, mica schists and amphibolites in contact with banded tonalitic-granodioritic Amitsoq gneisses. This sequence is compared and contrasted with the Malene supracrustal sequence on Qilangârssuit and the surrounding islands (fig. 1).

\section{East Simuitâ}

At this locality a Malene supracrustal sequence is mirrorred in a $D_{4}$-refolded $D_{3}$ isoclinal structure (terminology of Chadwick \& Nutman, 1979) and is bounded on both sides by Amitsoq gneisses. This sequence can be divided into three units (fig. 2). The contact between the Malene rocks and Amitsoq gneisses is generally sharp, with no concentration of veining, intense shearing, mylonitisation or interdigitation (either tectonic or by intrusive sheeting). However, there is some difficulty locally in identifying Amîtsoq gneisses within 1 or $2 \mathrm{~m}$ of the contact. Lithological units of the Malene sequence are not seen to be truncated at the contact. We interpret the contact as a deformed unconformity not as a major tectonic break. This gives the following succession; Amîtsoq gneiss basement, banded white quartzite unit ( 1 to $20 \mathrm{~m}$ thick), mica schist with metachert unit (less than $5 \mathrm{~m}$ thick) and the amphibolite unit (more than $30 \mathrm{~m}$ thick).

At the base of the banded white quartzite unit a thin mica-rich layer is developed locally. This 'basal sediment' may represent a regolith. Individual layers in the banded white 

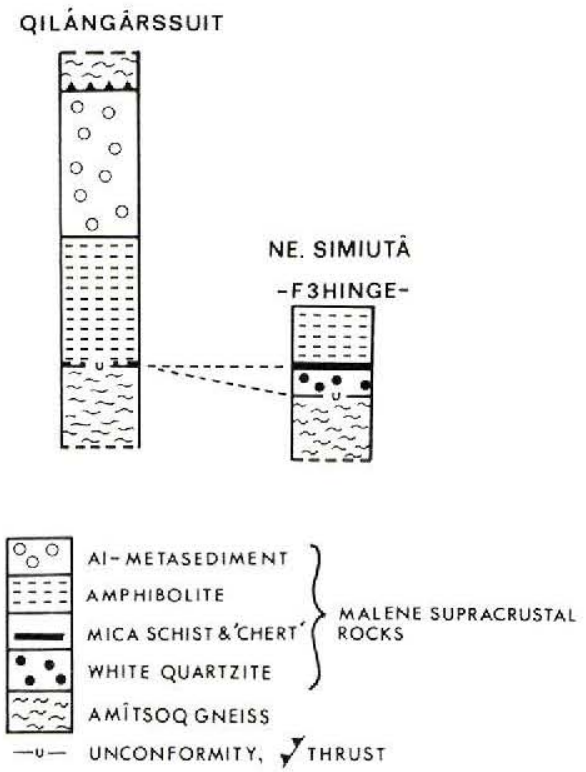

Fig. 2. Schematic stratigraphic columns of Malene sequences on Qilángârssuit and eastern Simuitâ.

quartzites are continuous laterally with respect to their thickness. The banding of these rocks is interpreted as sedimentary bedding that was accentuated during subsequent deformation. Graded bedding has not been observed. Layers with appreciable amounts of feldspar occur sporadically throughout the unit, but are commonest in the lower parts. The bedding is demarcated by black laminae containing biotite. Zircon is an accessory mineral in the quartzites; laboratory studies on separated heavy minerals from these rocks are in progress. Green (chromiferous) mica occurs near the top of the unit locally. The quartzites are cut by quartz veins, some of which seem to be geometrically related to small folds.

A unit of mica schist with layer(s) of coarse-grained quartz-rich rock conformably overlies the banded white quartzites. Small irregularities are seen along the boundary between the units. In the south-western part of the sequence bedding at the top of the banded white quartzite is truncated by a depression $10 \mathrm{~cm}$ long and $3 \mathrm{~cm}$ deep. There is no evidence for post-sedimentation intense strain or veining at this locality and we interpret the feature as a scour at the top of the quartzites infilled by the protolith of the overlying mica schists and showing younging away from the gneiss contact. Both the mica schist and the associated quartz-rich rock contain chromiferous mica. The mica schists are generally biotite-rich with diffuse compositional banding. They contain buff and white-coloured lenses and augen of feldspar, sillimanite and pale mica. The quartz-rich rocks occur in the upper part of the unit. Some are conformable within the sequence, whilst others are clearly veins. The conformable quartz-rich rocks are massive, locally rusty westhering and consist of translucent coarse-grained quartz with small disseminated flecks of Fe-oxide, chromiferous mica, garnet and amphibole. The platy and prismatic minerals are aligned to form a weak compositional banding. These quartz-rich rocks show no evidence of detrital origin and therefore are provisionally interpreted as metacherts. In some sections there is an alternation of mica 
schist and metachert. It is not certain if this is an original feature or whether it is due to small-scale folding.

The amphibolite unit overlies the mica schist with metachert unit. Commonly, the contact between them is conformable, but locally it has been tectonised, resulting in quartz-veining and local discordances between compositional banding of the units at the contact. The amphibolite unit comprises banded amphibolites and massive melanocratic amphibolites with associated ultramafic rocks. The amphibolites contain hornblende, diopside and plagioclase and are banded on a 2 to $15 \mathrm{~cm}$ scale. Upwards they are more closely banded and more leucocratic. The banding is locally interrupted by coarser-grained lenses and stringers, which possibly formed as incipient partial melt sweats under amphibolite facies conditions. The middle part of the unit is dominated by more massive melanocratic amphibolites with associated ultramafic pods. The melanocratic amphibolite member has some (contorted) compositional banding, particularly towards its top. The ultramafic pods occur towards the base of the melanocratic amphibolite member and have diverse mineralogies. Some are

Table 2. Analyses of representative Malene supracrustal rocks, eastern Simuitâ

\begin{tabular}{|c|c|c|c|c|}
\hline & $243057 \mathrm{c}$ & $243060 \mathrm{~b}$ & 243050 & $243050 a$ \\
\hline $\mathrm{SiO}_{2}$ & $87 \cdot 80$ & $80 \cdot 31$ & $63 \cdot 60$ & $64 \cdot 80$ \\
\hline $\mathrm{TiO}_{2}$ & 0.08 & $0 \cdot 20$ & $0 \cdot 70$ & 0.53 \\
\hline $\mathrm{Al}_{2} \mathrm{O}_{3}$ & $6 \cdot 32$ & $10 \cdot 53$ & $18 \cdot 85$ & $16 \cdot 38$ \\
\hline $\mathrm{Fe}_{2} \mathrm{O}_{3}$ & 0.00 & 0.00 & 0.49 & $0 \cdot 33$ \\
\hline $\mathrm{FeO}$ & $0 \cdot 10$ & $1 \cdot 52$ & $3 \cdot 73$ & $4 \cdot 35$ \\
\hline $\mathrm{MnO}$ & $0 \cdot 00$ & 0.08 & 0.06 & $0 \cdot 05$ \\
\hline $\mathrm{MgO}$ & $0 \cdot 02$ & $0 \cdot 41$ & $2 \cdot 48$ & $2 \cdot 74$ \\
\hline $\mathrm{CaO}$ & $0 \cdot 01$ & $1 \cdot 61$ & $1 \cdot 43$ & $2 \cdot 57$ \\
\hline $\mathrm{Na}_{2} \mathrm{O}$ & $0 \cdot 61$ & $2 \cdot 85$ & $0 \cdot 50$ & $3 \cdot 70$ \\
\hline $\mathrm{K}_{2} \mathrm{O}$ & $4 \cdot 50$ & $1 \cdot 28$ & $5 \cdot 55$ & $2 \cdot 63$ \\
\hline 1.o.i. & $0 \cdot 14$ & $0 \cdot 43$ & $2 \cdot 12$ & $0 \cdot 94$ \\
\hline $\mathrm{P}_{2} \mathrm{O}_{5}$ & $0 \cdot 02$ & 0.03 & 0.04 & $0 \cdot 00$ \\
\hline Total & $99 \cdot 61$ & $99 \cdot 25$ & $99 \cdot 55$ & $99 \cdot 02$ \\
\hline $\mathrm{Rb}$ & 99 & 32 & 158 & 189 \\
\hline $\mathrm{Sr}$ & 37 & 148 & 61 & 160 \\
\hline $\mathrm{Ba}$ & 561 & 299 & 1196 & 1181 \\
\hline $\mathbf{Y}$ & 11 & 14 & 26 & 9 \\
\hline $\mathrm{Zr}$ & 142 & 90 & 416 & 274 \\
\hline $\mathrm{Pb}$ & 14 & 16 & 15 & 43 \\
\hline $\mathrm{Cr}$ & 21 & 53 & 389 & 678 \\
\hline $\mathrm{Ni}$ & n.d. & 13 & 150 & 200 \\
\hline
\end{tabular}

$243057 \mathrm{c}$ and $243060 \mathrm{~b}$, layered white quartzite. GGU 243050 and $243050 \mathrm{a}$, mica schist. Major and minor element data produced by X.R.F. methods at the Geological Survey of Greenland. Trace element data produced by X.R.F. methods at the Geology Department, University of Nottingham. 
coarse-grained with relict orthopyroxene, whilst others are phlogopite-bearing hornblendites. Poor exposure and the intense reformation around the margins of the ultramafic bodies make it impossible to decipher their relations with the adjacent amphibolites. Like similar bodies on Qilángârssuit (Chadwick, 1981), they could be associated with the melanocratic amphibolite, being a cumulate-rich facies of a differentiated basic flow or sill.

If the Malene sequence on eastern Simuitâ is considered to rest on a continental basement of Amîtsoq gneiss, the banded white quartzite unit (representative analyses, Table 2) is interpreted as a sequence of detrital sediments of sialic provenance, their source presumably being the basement Amîtsoq gneisses. These quartzites bear some lithological resemblance to the basal quartzites of the Cambro-Ordovician shelf sequences of the north Atlantic (e.g. Swett \& Smit, 1972). Unfortunately, few sedimentary structures have survived in the Malene quartzites, and thus they cannot be compared in detail with better-preserved sequences.

The two samples of the mica schists analysed (Table 2) have high $\mathrm{FeO}, \mathrm{MgO}, \mathrm{Ni}$ and $\mathrm{Cr}$ contents, a common feature of Archaean mica schists. This suggests that they have been derived form either fine-grained altered basic tuffs or pelites derived from weathered basic rocks. The origin of the associated metachert is uncertain. These rocks may represent rapid precipitation of $\mathrm{SiO}_{2}$ due to chemical changes in the seawater, perhaps representing periods of evaporation or contemporary volcanism. Banded amphibolites such as those of the Malene amphibolite unit on Simuitâ can be formed by deformation of a varity of original rock types (Ehlers, 1976; Bridgwater et al., 1976; Hall, 1980). In these outcrops which are less deformed than many Malene sequences no structures resembling deformed pillow lavas are seen. Our preferred explanation of the unit is that the protolith was layered and represents basic tuffs possibly interlayered with differentiated flows or sills.

\section{Qilángârssuit and surrounding islands}

The Malene supracrustal rocks of this area were studied by A. P. N. in 1976 and 1977. They can be divided into the amphibolite and Al-rich metasediment unit comprises the Qilángârssuit and Simiútat Malene gneiss groups of Beech \& Chadwick (1980). In the Al-rich metasediment unit a structure which may be cross-bedding is preserved locally (Beech \& Chadwick, 1980). The way-up indicated by the cross-bedding shows that the Al-rich metasediment unit overlies the amphibolite unit.

At the base of the Malene supracrustal sequence on Qilángârssuit, either banded amphibolites, thin non-detrital quartzites (metacherts?) or mica schists are in sharp contact with (originally underlying) Amitsoq gneisses. Long sections of this contact show no evidence of being a tectonic break; there is no shearing, veining, interdigitation or cataclasis. The interpretation of this contact as a deformed unconformity (Chadwick \& Nutman, 1979) is preferred. Some sections of this contact are sheared and veined, but there is commonly evidence that at least some of the movement occurred late in the structural history.

A basal conglomerate is not present in the Malene sequence of Qilángârssuit, but there is a thin mica schist unit or a seam of the non-clastic quartzite along much of the its base. The mica schist contains biotite, green (chromiferous) mica, quartz, microcline and plagioclase, commonly with accessory zircon, monazite and rutile. This rock was interpreted as a "basal sediment' by Chadwick \& Nutman (1979). The non-clastic quartzites are variable. Some are clearly vein complexes along the contact, but the majority occur as seams up to $1.5 \mathrm{~m}$ thick 
of faintly-laminated quartzite that can be followed along the contact for hundreds of metres. Although these seams show some evidence of mobility locally, they are too regular and continuous to be interpreted as veins. Our favoured interpretation is that they are a thin metachert unit. The faint lamination in these rocks is formed by flecks of the green (chromiferous) mica and amphibole. The overlying amphibolite unit comprises banded plagioclase-hornblende-clinopyroxene-garnet amphibolites interdigitated with homogeneous garnetiferous amphibolite. Near the base of the amphibolite unit there are lenticles of ultramafic rock in various states of preservation, some contain relict pyroxene, whilst others are phlogopite-bearing amphibole rocks. The boundary between the amphibolite unit and the overlying Al-rich metasediment unit is commonly somewhat arbitrary due to some interlamination of the amphibolites and sediments. The dominant lithologies of the Al-rich metasediment unit are laterally variable garnet-sillimanite-biotite-quartz-feldspar and cordierite-anthophyllite mica-quartz gneisses. Generally, all primary structures have been obliterated apart from megascopic compositional banding. However, possible cross-bedding is preserved locally, suggesting the way-up of the sequence (Beech \& Chadwick, 1980).

Contacts between the Al-rich metasediments and the adjacent Amitsoq gneisses which overlie them structurally are all tectonic with intense local shearing, veining, minor interdigitation of lithologies and cataclasis. The tectonic juxtaposition of these rocks occurred early in the structural development of the area, because the tectonic breaks ( $D_{2}$ thrusts) are folded by $D_{3}$ isoclines of nappe-like dimensions (Chadwick \& Nutman, 1979). The thrust(s) cut obliquely through the Malene sequence on Qilángârssuit, resulting in the progressive cutting-out northwards of the $\mathrm{Mg}$-rich metasediment and then the amphibolite units (see fig. 1 of Beech \& Chadwick, 1980). Following the regional structure, Malene rocks should outcrop on the islands to the north of Qilángârssuit. As this is not the case, then it is likely that off north Qilángârssuit the thrust cuts out the Malene sequence completely, and lies entirely within Amîtsoq gneisses.

The Malene sequences on Qilángârssuit and surrounding islands are interpreted as follows. The mica schists and non-clastic quartzites are 'basal sediment', the mica schists perhaps derived from a regolith mixed with pelitic material from weathered basic rocks, whilst the non-clastic quartzites originated as cherts. The amphibolite unit is interpreted as a pile of basic volcanic rocks with differentiated flows or sills (Chadwick, 1981). Beech \& Chadwick (1980) and Beech (1979) discussed in detail the origin and significance of the Mg-rich metasediment unit, and they consider the protoliths were mixtures of precipitated Mg-rich clay minerals and detrital quartz.

\section{Discussion}

The combined field evidence from Simuitâ and Qilángârssuit strongly support the contention that parts of the Malene supracrustal succession was deposited on an older sialic basement of Amîtsoq gneiss. A detailed stratigraphy is presented for these lower units which have a present maximum thickness of less than $500 \mathrm{~m}$ and it is suggested that the depositional environment changes from locality to locality within the area studied. The first stage of Malene sedimentation in this area was local deposition of quartzo-feldspathic detrital material possibly on a weathered regolith. This was followed by a mica schist unit, in some places deposited directly on an Amitsoq gneiss basement in others on detrital sediments. 
This more continuous unit can be used as a marker horizon and is followed by an amphibolite unit interpreted as representing basic volcanism. In the southern part of the area the basic volcanics are overlain by an Al-rich metasedimentary unit derived from clays and detrital quartz. This upper unit is cut out by thrust contacts in the northern part of the area. The sediments can be interpreted as having a composite source, the quartz-rich arkoses must be derived from preexisting sialic material while the mica-schists and the A1-rich metasediments could be derived from a basic or mixed sialic parent. The local variations in the stratigraphy and the evidence for a variable source strongly suggest that this group of Malene supracrustal rocks was deposited in near-shore conditions rather than oceanic basins, possibly with semi-contemporanceous basic volcanism. While the obvious source for the sialic component in the present outcrops is an Amitsoq gneiss basement, there is no reason why sialic material in some units of Malene supracrustals should not be derived from intermediate or acid volcanism at the onset of Nûk plutonism (Hamilton et al., 1983). We consider it no longer appropriate to treat Malene supracrustal sequences from the different thrust slices established by McGregor (1973) as necessarily of the same general age or depositional environment.

The Amîtsoq gneisses south of Godthåb were metamorphosed to granulite facies and were at a depth of at least $25 \mathrm{~km}$ in the crust at $3.600-3.500 \mathrm{Ma}$ (Griffin et al., 1980). Therefore, deposition of Malene supracrustal rocks on an Amitsoq basement implies that there must have been considerable erosion of the Amitsoq 'continent' between 3500 and $3100 \mathrm{Ma}$. Furthermore, if (some of) the Amîtsoq 'continent' was subaerially-exposed in the Archaean, then deposition of the Malene sequence upon it implies that subsidence also occurred. This could be achieved by crustal-thinning in a tensional zone.

Throughout the region the Ameralik dyke swarm (Table 1) is prolific and all but the oldest of the Ameralik dyke lithotypes can be matched with dykes cutting the Malene rocks (Chadwick, 1981). It is possible that some Ameralik dykes could be feeders to the volcanic components of the Malene sequence, deposited on a thinned Amitsoq basement in a zone of tension. Continuation of such ensialic rifting could have led to the deposition of supracrustal sequences not resting on a sialic basement, but of approximately the same age as the Malene supracrustal rocks (see Hall \& Friend, 1979; Hall, 1980).

Acknowledgments. The conclusions reached are those from our own field and laboratory work and were circulated in manuscript to those interested in problems of Malene depositional environments. The final presentation is in turn influenced by discussion with V. R. McGregor, B. Chadwick, C. R. L. Friend, P. Hall and by manuscripts by Dymek et al. (this report), Hamilton et al. (1983), and S. M. McClennan, S. R. Taylor \& V. R. McGregor (unpublished) which contain information which give support to, or in some cases constraints on, the ideas expressed.

\section{References}

Baadsgaard, H. 1976: Further U-Pb dates on zircons from the early Precambrian rocks of the Godthåbsfjord area, W. Greenland. Earth planet. Sci. Lett. 33, 261-267.

Baadsgaard, H. \& McGregor, V. R. 1981: The U-Th-Pb systematics of zircons from the type Nûk gneisses, Godthåbsfjord, West Greenland. Geochim. cosmochim. Acta. 45, 1099-1109. 
Bridgwater, D., McGregor, V. R. \& Myers, J. S. 1974: A horizontal tectonic regime in the Archaean of Greenland and its implications for early crustal thickening. Precambrian Res. 1, 179-197.

Bridgwater, D., Keto, L., McGregor, V. R. \& Myers, J. S. 1976. Archaean gneiss complex of Greenland. In Escher A. \& Watt, W. S. (edit) Geology of Greenland, 18-75. Copenhagen: Geol. Surv. Greenland.

Bridgwater, D., Allaart, J. H., Baadsgaard, H., Collerson, K. D., Ermanovics, I., Gorman, B. E., Griffin, W., Hanson, G., McGregor, V. R., Moorbath, S., Nutman, A. P., Taylor, P., Tveten, E. \& Watson, J. 1979: International field work on Archaean gneisses in the Godthåbsfjord-Isua area, southern West Greenland. Rapp. Grønlands geol. Unders. 95, 66-71.

Beech, E. M. 1979: The origin and significance of the Malene supracrustal rocks from the islands of the northwest Buksefjorden region, southern West Greenland. Unpublished Ph.D. thesis, Univ. of Exeter.

Beech, E. M. \& Chadwick, B. 1980: The Malene supracrustal gneisses of northwest Buksefjorden: their origin and significance in the Archaean crustal evolution of southern West Greenland. Precambrian Res. 11, 329-355.

Chadwick, B. 1981: Field relations, petrography and geochemistry of Archaean amphibolite dykes and Malene supracrustal amphibolites, northwest Buksefjorden, southern West Greenland. Precambrian Res. 14, 221-257.

Chadwick, B. \& Nutman, A. P. 1979: Archaean structural evolution in the northwest of the Buksefjorden region, southern West Greenland. Precambrian Res. 9, 199-226.

Dymek, R. F., Weed, R. \& Gromet, L. P. 1983: The Malene sedimentary rocks on Rypeø, and their relationship to Amîtsoq gneisses. Rapp. Grønlands geol. Unders. 112, 53-69.

Ehlers, G. 1976: Homogeneous deformation in Precambrian rocks of the Kumlinge area, southwest Finland. Precambrian Res. 3, 481-504.

Griffin, W. L., McGregor, V. R., Nutman, A. P., Taylor, P. N. \& Bridgwater, D. 1980: Early Archaean granulite-facies metamorphism south of Ameralik, West Greenland. Earth planet. Sci. Lett. 50, 59-74.

Hamilton, P. J., O'Nions, R. K., Bridgwater, D. \& Nutman, A. 1983: Sm-Nd studies on Archaean metasediments and metavolcanics from West Greenland and their implications for the Earth's early history. Earth planet. Sci. Lett. 62, 263-272.

Hall, R. P. 1980: The tholeiitic and komatiitic affinities of the Malene metavolcanic amphibolites from Ivisârtoq, southern West Greenland. Rapp. Grønlands, geol. Unders. 97, 1-20.

Hall, R. P. \& Friend, C. R. L. 1979: Structural evolution of the Archaean rocks in Ivisârtoq and the neighboring inner Godthåbsfjord region, southern West Greenland. Geology 7, 311-315.

McGregor, V. R. 1973: The early Precambrian gneisses of the Godthåb district, West Greenland. Phil. Trans. R. Soc. Lond. A273, 343-358.

Swett, K. \& Smit, D. E. 1972: Paleogeography and depositional environment of the Cambro-Ordovician shallow-marine facies of the north Atlantic. Bull. geol. Soc. Am. 83, 3223-3248.

D.B., 